\title{
Quality of Wood and Charcoal from Eucalyptus Clones for Metallurgical Use
}

\author{
Diego Correa Ramos ${ }^{1}$, Angélica de Cássia Oliveira Carneiro ${ }^{1}$ (D), \\ Merete Tangstad $^{2}$, Raghed Saadieh ${ }^{2}$, Bárbara Luísa Corradi Pereira ${ }^{3}$ \\ ${ }^{1}$ Departamento de Engenharia Florestal, Universidade Federal de Viçosa - UFV, Viçosa/MG, Brasil \\ ${ }^{2}$ Norwegian University of Science and Technology - NTNU, Trondheim/ Sør-Trøndelag, Norway \\ ${ }^{3}$ Universidade Federal de Mato Grosso - UFMT, Cuiabá/ MT, Brasil
}

\begin{abstract}
The objectives of the present work were to determine the properties of wood and charcoal from Eucalyptus clones and assess impacts of charcoal features on the $\mathrm{CO}_{2}$ gasification reactivity and to compare with coke reactivity. Gasification reactivity was performed using charcoal particles in a furnace setup at $820^{\circ} \mathrm{C}$, under $\mathrm{CO}_{2}$ atmosphere. The results show that there is wood variability among evaluated clones and strong correlations between wood and charcoal properties. All charcoals had higher reactivity in comparison to coke. The decrease in porosity and increase in apparent density in Eucalyptus wood led to a slight decrease of $\mathrm{CO} 2$ gasification reactivity. In addition, strong positive correlation between charcoal reactivity and potassium concentration $(\mathrm{K})$ was found.
\end{abstract}

Keywords: $\mathrm{CO}_{2}$ gasification, reductant materials, biocarbon. 


\section{INTRODUCTION}

Brazil is the world's leading producer of charcoal for industrial purposes, mainly used in the production of pig iron and steel, followed by ferrous alloys and silicon. It is noteworthy that the production of metal silicon by the metallurgical industry in Brazil is exclusively made with the use of charcoal, while in other countries, the use of coal is predominant.

Charcoal in the metallurgical industry acts as a bio-reducing agent and its use presents some advantages compared to fossil reductants, such as coal and coke. Charcoal has high reactivity, high porosity, high resistivity and low percentage of ashes, e.g. sulphur and phosphorus (Wang et al., 2016; Babich et al., 2010). Additionally, compared to the use of fossil reductants, the use of charcoal radically reduces $\mathrm{SO}_{2}$ emissions, and helps reduce the environmental impact of $\mathrm{CO}_{2}$. On the other hand, charcoal has much lower mechanical strength compared to coal and coke, which might be challenging for some metal production processes. However, charcoals can be produced from different raw materials and under various process conditions, and have different properties influencing further applications (Kan et al., 2016; Oliveira et al., 2010).

Reactivity towards $\mathrm{CO}_{2}$ is one of the most important properties of carbon materials used as reductants during metallurgical production processes (Wang et al., 2016). Reactivity should be appropriate for specific metallurgical processes to ensure optimum reduction process. In this study, the main objective was to assess the $\mathrm{CO}_{2}$ reactivity of charcoal from Eucalyptus clones and to compare with coke reactivity.

\section{MATERIALS AND METHODS}

\subsection{Raw material: sampling and characterization}

Three short-rotation forestry species, Eucalyptus urophylla vs grandis hybrid clones, named as CL-1, CL-2 and CL-3, were used for this study. Samples of 7-year-old wood were collected from a Brazilian forestry company. These materials were selected due to the density variations. Six logs, representative of diameter variations, were sawn into 50 -mm thick (discs), then divided in four to be used in chemical and physical analyses.

The wood basic density was determined according to NBR 11941 (ABNT, 2003). To determine macromolecular composition (lignin, extractives and holocellulose content) and ash content, samples were crushed and sieved between 250 and $400 \mu \mathrm{m}$. Wood extractive content was determined according to TAPPI 204 om- 88 (TAPPI, 2001), using the total extractive method but substituting ethanol/benzene by ethanol/toluene. Lignin content was obtained by the sum of soluble and insoluble lignin. Insoluble lignin was determined using Klason method, which was modified according to procedure proposed by Gomide \& Demuner (1986). Holocellulose content was determined by difference, based on extractive-free wood.

From each clone, logs with diameters from 60 to $140 \mathrm{~mm}$ were selected and sawn into pieces of approximately $1.0 \mathrm{~m}$ in height for carbonization. Charcoal was produced using a laboratory kiln built of refractory bricks, with diameter of $1.2 \mathrm{~m}$ and height of $1.1 \mathrm{~m}$, with $1.04 \mathrm{~m}^{3}$ of usable volume. The peak carbonization temperature was about $380^{\circ} \mathrm{C}$ and the total carbonization time was approximately 50 hours. After carbonization, six 20-L bags of charcoal were randomly collected, homogenized and quartered. Samples were collected to determine charcoal properties.

\subsection{Charcoal preparation}

Charcoals from the three different clones were used in this study. In addition, one type of metallurgical coke was investigated as a reference material. Charcoals were produced in a laboratory kiln built of refractory bricks, with diameter of $1.2 \mathrm{~m}$ and height of $1.1 \mathrm{~m}$, with $1.04 \mathrm{~m}^{3}$ usable volume. About $0.6 \mathrm{~m}^{3}$ of logs were loaded into the kiln for pyrolysis. Internal heating was used to initiate pyrolysis and maintain temperatures during the process. Temperature was monitored by five thermocouples, one inserted at the dome of the kiln and the others on the wall. The temperature of the carbonization process was controlled according to a pre-set theoretical model. The peak carbonization temperature was about $380{ }^{\circ} \mathrm{C}$. This temperature was used for maximizing charcoal yield. 


\subsection{Charcoal properties}

Proximate analysis of produced charcoals was performed according to procedures described in D1762-84 ASTM standard (ASTM, 2013). The ultimate analysis was determined by using an elemental Eurovector EA 3000 CHNS-O Elemental Analyzer. Concentrations of inorganic elements in the produced charcoal were measured by means of an inductively coupled plasma optical emission spectrometry (ICP-OES). Silicon content was determined by $\mathrm{X}$-ray fluorescence technique (XRF).

Apparent density (AD) was determined by the hydrostatic method, in which samples were immersed in mercury. Therefore, it was possible to obtain the fixed carbon stock (FCS), expressed in $\left(\mathrm{kg} \mathrm{m}^{3}\right)$, by the product of charcoal apparent density and fixed carbon content.

Absolute density was determined using an AccuPyc 1330 Helium Pycnometer. The material porosity was evaluated according to the equation 1 below:

Porosity $=\left[1-\left(\frac{\text { apparent density }}{\text { absolute density }}\right) 100 \%\right]$
Friability (denoted F, expressed in \%) also named "impact strength" gives an idea of the extent of breakage that will occur during charcoal loading, transportation and screening. In this work, the drum test was used to determine the charcoal friability index or degree. The procedure was performed according to Noumia et al. (2016).

Charcoal morphology was investigated by field-emission scanning electron microscopy (LVFESEM, Zeiss Supra 55VP).

\section{4. $\mathrm{CO}_{2}$ reactivity apparatus and procedures}

Charcoal samples were calcined in an induction furnace to remove volatile matter, prior to $\mathrm{CO}_{2}$ reactivity tests. Thereafter, samples were crushed and screened to the fraction $+2-4.5 \mathrm{~mm}$ mesh to be used in the reactivity test. The $\mathrm{CO}_{2}$ reactivity test was performed in an electric tube vertical furnace (Figure 1).

In the electric tube vertical furnace experiments, nitrogen flow of $0.81 . \mathrm{min}^{-1}$ was used to sweep char sample during the heating up period from the room temperature to the desired gasification temperature of $820^{\circ} \mathrm{C}$. Heating up was carried out at a nominal heating rate of $35^{\circ} \mathrm{C} \mathrm{min}{ }^{-1}$. As temperature reached $820{ }^{\circ} \mathrm{C}$, the purge gas was shifted from $\mathrm{N}_{2}$ to $\mathrm{CO}_{2}$. The sample

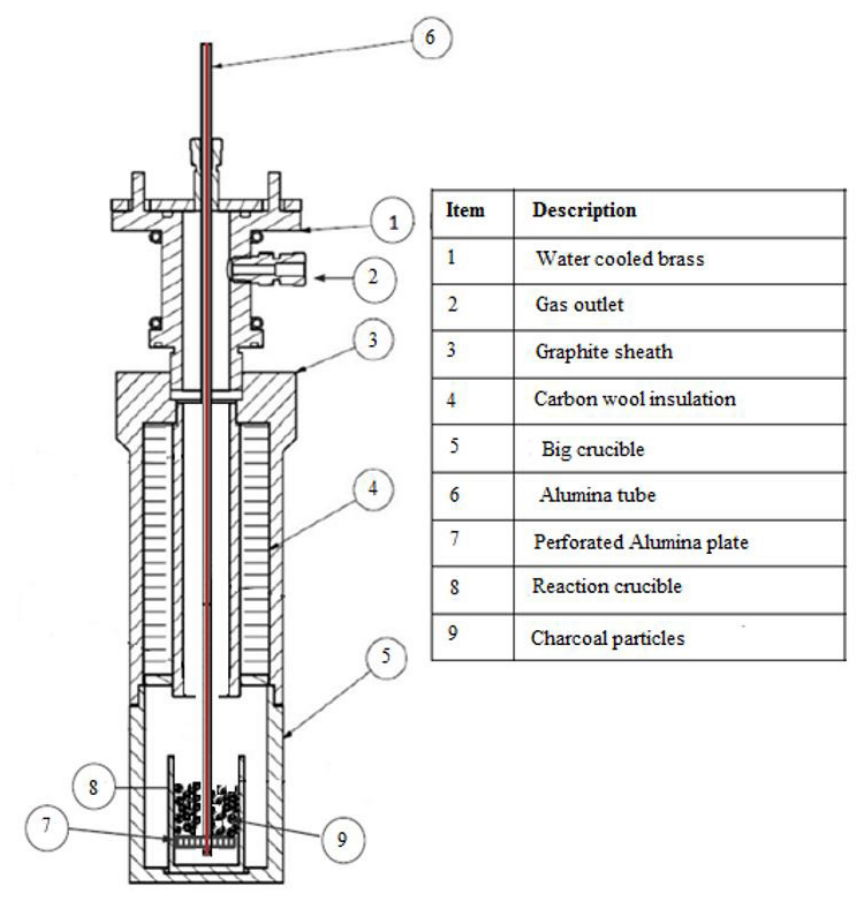

Figure 1. Apparatus used for the $\mathrm{CO}_{2}$ reactivity experiment. 
was kept at final temperature in the presence of $\mathrm{CO}_{2}$ for $60 \mathrm{~min}$. The experiment was then cooled down under $\mathrm{N}_{2}$ atmosphere to room temperature. Reactivity $(\mathrm{Rn})$ was evaluated according to the equation 2 below:

$$
\mathrm{Rn}=\frac{\left(\mathrm{m}_{2}-\mathrm{m}_{1}\right)}{\left(\mathrm{t}_{2}-\mathrm{t}_{1}\right) * \mathrm{~m}_{1}}
$$

Where:

$\mathrm{Rn}=$ reactivity at time $\mathrm{t}$

$\mathrm{t}_{1}=$ time of start of the weight measurement

$\mathrm{t}_{2}=$ time of end of the weight measurement

$\mathrm{m}_{1}=$ sample mass at $\mathrm{t}_{1}$

$\mathrm{m}_{2}=$ sample mass at $\mathrm{t}_{2}$

\subsection{Statistical analysis}

The experiment was performed according to a randomized design with four treatments (carbon reductants) and two replicates (two-sample), totaling 8 sampling units. Data normality was verified by Lilliefors test and homogeneity of variance by Cochran. Thereafter, data were subjected to analysis of variance, and, when significant differences were established, treatments were compared through the Tukey test at $5 \%$ probability. The accuracy of measurements was assessed with the sample standard deviation, which represents the mean deviation observed of values from their mean.

\section{RESULTS AND DISCUSSION}

\subsection{Wood characterization}

Charcoal quality, among other factors, is a function of its parental wood. Thus, assessment of wood properties is also necessary for better understanding of charcoal properties. Additionally, information on wood properties are necessary to achieve efficient pyrolysis, good quality of charcoal and low cost.

The chemical composition of Eucalyptus feedstock are listed in Table 1. The clone CL-3 had the highest levels of lignin (31.5\%) and the lowest of holocellulose
(64.5\%), however, these components did not differ significantly among the clones. The lignin content is an important parameter to be evaluated in production and quality of charcoal, because within molecular chemicals elements of wood it is the one that presents greater resistance to thermal degradation (Pereira et al., 2013b; Yang et al., 2007; Raad et al., 2006) and, consequently, has positive influence in charcoal yield (Pereira et al., 2012; Trugilho et al., 2011). However, additionally, the quality of the lignin (syringyl/guaiacyl ratio) should also be considered (Soares et al., 2014; Santos et al., 2016). According to Pereira et al. (2013a), a minimum lignin content of $28 \%$ is required for profitable charcoal production for industrial purposes.

The content of extractives of CL-1 clone was the highest, average extractives of $4.5 \%$, followed by CL-3 (3.9\%) and CL-1 (3.3\%). The content of extractives differed statistically among clones. The variation of extractives content can be attributed to different proportions of heart and sapwood, as well as to losses of extractives due to timber storage time (Costa et al., 2017; Pereira et al., 2013c; Silverio et al. 2008).

As it can be seen from Figure 2, the wood basic density ranged from 459.8 to $559.2 \mathrm{~kg} \mathrm{~m}^{-3}$ among evaluated clones. CL-1 clone presented the highest

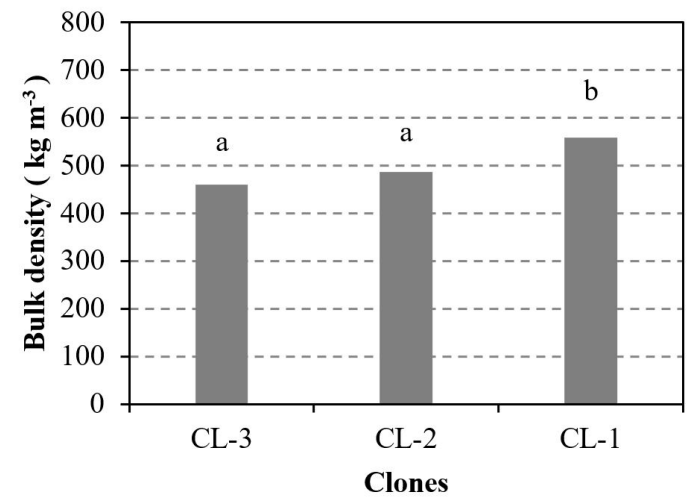

Figure 2. Mean wood basic density values $\mathrm{kg} \mathrm{cm}-3$ from Eucalyptus clones. Standard deviation $=40.3$; variation coefficient $=7.9 \%$. Means followed by same letter do not differ at $5 \%$ probability by the Tukey test.

Table 1. Mean of holocellulose, lignin and extractives values of Eucalyptus clones.

\begin{tabular}{cccc}
\hline CLONE & Lignin $^{\star}(\%)$ & Holocelullose (\%) & Extratives (\%) \\
\hline CL-3 & $31.5 \pm 1.9 \mathrm{a}$ & $64.5 \pm 1.9 \mathrm{a}$ & $3.9 \pm 0.02 \mathrm{~b}$ \\
CL-2 & $29.4 \pm 0.9 \mathrm{a}$ & $67.2 \pm 1.1 \mathrm{a}$ & $3.3 \pm 0.07 \mathrm{a}$ \\
CL-1 & $29.6 \pm 0.4 \mathrm{a}$ & $65.8 \pm 0.5 \mathrm{a}$ & $4.5 \pm 0.03 \mathrm{c}$ \\
\hline
\end{tabular}

${ }^{*}$ Extractive-free wood. Means in the column followed by the same letter do not differ at $5 \%$ of probability by the Tukey Test. ( \pm ) Standard deviation. 
average basic density, $559.2 \mathrm{~kg} \mathrm{~m}^{-3}, 18.2 \%$ higher than the mean value of the other clones.

Basic density should be considered one of the main criteria for selection of species and clones of Eucalyptus for charcoal production. High-density wood with is usually preferred, because the use of denser woods results in higher charcoal production for a certain volume of wood placed in the kiln (Pereira et al., 2012; Neves et al., 2011). Moreover, wood density is positively correlated to charcoal apparent density. Denser wood produces denser charcoal, thus, it is expected to have higher mechanical strength (Assis et al., 2016; Couto et al., 2015).

\subsection{Reductant material characterization}

Parameters that characterize the chemical properties of charcoal and coke are shown in Table 2. Inorganic elements are listed in Table 3.

FC showed small variation among charcoals, which is explained by the homogeneous pyrolysis conditions. The coke sample exhibited the highest FC as expected. The ash content of charcoal was less than $1 \%$ in all charcoal samples, whereas it was $6.9 \%$ in coke. Compounds that can be found in ashes are mainly metal oxides. Metals are reduced by carbon and are transferred to the metal alloy contaminating them, and in addition to influencing the chemical composition of the melted alloy, minerals can influence the properties of reducing materials (Gładysz \& Karbowniczek, 2008).

As it can be seen in Figure 3, there is significant variability of apparent density and fixed carbon stock among charcoals. CL-3 wood char presented the lowest apparent density and FCS values, followed by CL-2 and CL-1 respectively. These results can be attributed to the variability found in wood bulk density. The clone that stood out with the highest bulk density also presented the highest apparent density and fixed carbon stock values in charcoal. It is noteworthy that wood density and pyrolysis conditions are two factors that significantly affect the charcoal apparent density (Assis et al., 2016; Kan et al., 2016). Coke apparent density and fixed carbon values were 1024.5 and $911.8 \mathrm{~kg} \mathrm{~m}^{-3}$ respectively,

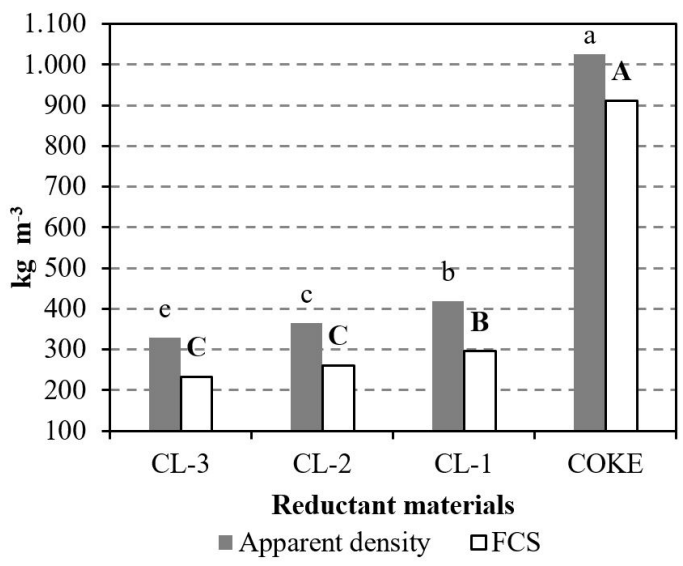

Figure 3. Mean apparent density (AD) and fixed carbon stock (FCS) values of reductant materials. Standard deviation $=53.9(\mathrm{AD}), 39.56(\mathrm{FCS})$; variation coefficient $=13.6 \%$ (AD), $13.8 \%$ (FCS). Means followed by same letter do not differ at $5 \%$ probability by the Tukey test.

Table 2. Proximate and ultimate analysis of charcoal samples (dry basis, wt \%).

\begin{tabular}{|c|c|c|c|c|c|c|c|c|c|}
\hline \multirow{2}{*}{ Sample } & \multicolumn{5}{|c|}{ Ultimate analysis (wt \%) } & \multirow{2}{*}{$\begin{array}{c}\text { Ratio } \\
\mathrm{O} / \mathrm{C}\end{array}$} & \multicolumn{3}{|c|}{ Proximate analysis (wt $\%)$} \\
\hline & C & $\mathbf{H}$ & $\mathbf{S}$ & $\mathbf{N}$ & $\mathbf{O}$ & & VM & FC & Ash \\
\hline CL-1 & $75.2 \mathrm{a}$ & $3.5 \mathrm{~b}$ & $0.01 \mathrm{a}$ & $0.6 \mathrm{a}$ & $20.7 b$ & $0.27 \mathrm{~b}$ & $28.7 \pm 0.2 b$ & $70.9 \pm 0.2 b$ & $0.4 \pm 0.01 \mathrm{c}$ \\
\hline CL-2 & $75.5 \mathrm{a}$ & $3.2 \mathrm{~b}$ & $0.01 \mathrm{a}$ & $0.7 \mathrm{a}$ & $20.2 \mathrm{~b}$ & $0.27 \mathrm{~b}$ & $28.1 \pm 0.1 \mathrm{~b}$ & $71.3 \pm 0.1 b$ & $0.7 \pm 0.02 \mathrm{bc}$ \\
\hline CL-3 & $76.4 \mathrm{a}$ & $3.4 \mathrm{~b}$ & $0.01 \mathrm{a}$ & $0.6 \mathrm{a}$ & $19.6 \mathrm{~b}$ & $0.26 \mathrm{~b}$ & $28.9 \pm 0.2 b$ & $70.6 \pm 0.3 \mathrm{~b}$ & $0.6 \pm 0.01 \mathrm{~b}$ \\
\hline COKE & $95.0 \mathrm{~b}$ & $1.7 \mathrm{a}$ & $0.30 \mathrm{~b}$ & $0.6 \mathrm{a}$ & $2.4 \mathrm{a}$ & $0.02 \mathrm{a}$ & $4.2 \pm 0.2 \mathrm{a}$ & $89.0 \pm 0.2 \mathrm{a}$ & $6.9 \pm 0.2 \mathrm{a}$ \\
\hline
\end{tabular}

C: carbon; H: hydrogen; S sulfur; N: nitrogen; O: oxygen; O/C: Oxygen/Carbon Ratio; VM: volatile matter; FC: fixed carbon. Means followed by same letter do not differ at $5 \%$ probability by Tukey test. $( \pm)$ Standard deviation.

Table 3. Ash composition of reductant materials.

\begin{tabular}{|c|c|c|c|c|c|c|c|c|c|c|c|}
\hline \multirow{2}{*}{ Sample } & \multicolumn{11}{|c|}{ Ash chemical composition (wt\%) } \\
\hline & $\mathrm{AlO}_{3}$ & $\mathrm{Fe}_{2} \mathrm{O}_{3}$ & $\mathrm{CaO}$ & $\mathrm{MgO}$ & $\mathrm{P}_{2} \mathrm{O}_{5}$ & $\mathrm{MnO}$ & $\mathrm{K}_{2} \mathrm{O}$ & $\mathrm{Na}_{2} \mathrm{O}$ & $\mathrm{TiO}_{2}$ & $\mathbf{S}$ & $\mathrm{SiO}_{2}$ \\
\hline CL-1 & 2.0 & 2.5 & 28.1 & 10.1 & 8.4 & 1.2 & 32.0 & 9.5 & 0.1 & 1.5 & 4.6 \\
\hline CL-2 & 0.4 & 0.7 & 22.7 & 11.3 & 7.9 & 1.2 & 47.8 & 4.9 & 0.0 & 1.1 & 2.0 \\
\hline CL-3 & 1.3 & 1.1 & 31.3 & 8.6 & 8.9 & 3.8 & 31.3 & 9.5 & 0.1 & 0.8 & 3.4 \\
\hline COKE & 17.4 & 15.9 & 14.5 & 8.7 & 0.1 & 0.6 & 0.9 & 2.3 & 0.7 & 4.3 & 34.5 \\
\hline
\end{tabular}


about 3 times higher than the average values of charcoal, which is mainly related to intrinsic characteristics of parental coal (Sakurovs \& Burke, 2011).

Figure 4 shows the scanning electron microscopy (SEM) images of wood and charcoal. In general, anatomical characteristics of wood, such as shape, arrangement and organization showed little or no alteration due to carbonization, and the charcoal surface presented well defined structures. These results are similar to those cited by Pereira et al. (2016), who characterized the anatomical properties of Eucalyptus ssp. and the microstructure of produced charcoal.

The porosity values of charcoals and coke are shown in Figure 5, and porosity values ranged from $42.2 \%$ to $77.2 \%$. Coke had the lowest porosity, $43 \%$ lower than the average values of charcoals. In addition, the high porosity and, hence, the low apparent density were related to higher charcoal friability. These results were similar to those found by several authors, among them Noumia et al. (2016) and Siebeneichler et al. (2017).

$\mathrm{CO}_{2}$ gasification reactivity can be seen in Figure 6. All charcoals had significantly higher reactivity than coke.
The charcoal characteristics, such as high porosity, low apparent density and reduced fiber wall fraction, which are indices connected to pore development in charcoal, should facilitate $\mathrm{CO}_{2}$ diffusion into the carbon matrix when compared to coke. However, among Eucalyptus wood chars studied, the contribution of pore structure in changing activities seems to be relatively small. As it can be seen in Figure 4 and 5, although CL- 2 charcoal presented intermediate porosity levels, it had the highest $\mathrm{CO}_{2}$ gasification reactivity, 33\% higher than the average of the other charcoals. By observing the ash chemical composition in Table 3, CL-2 charcoal presented the highest potassium concentration $(\mathrm{K})$, 1.5 times higher than CL-3 and CL-1charcoals. These indicate that the catalytic activity of potassium may have higher influence on charcoal gasification reactivity than porosity. It is known that the presence of $\mathrm{K}$ in charcoal improved its reactivity for $\mathrm{CO}_{2}$ catalytically gasification (Mitsuoka et al., 2011; Kaczorowski et al., 2007). Additionally, it is worth noting that the $\mathrm{CO}_{2}$ kinetic gasification of porous carbon at low temperature, where gaseous reactant molecules entering the porous
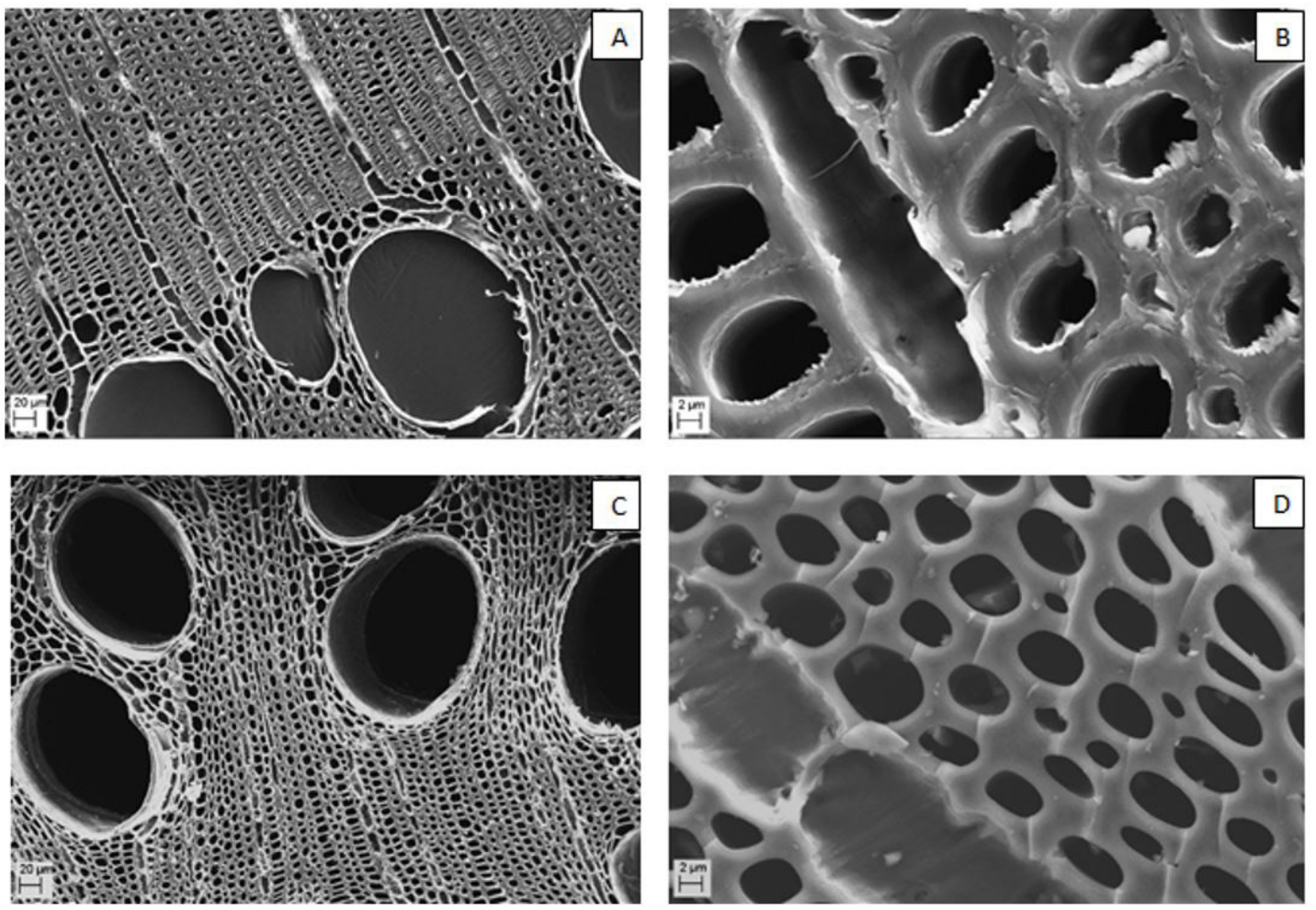

Figure 4. Scanning electron microscopy image of the transversal section of wood and charcoal from CL-1 Eucalyptus clone. (A) Wood; (B) details of wood fibers and parenchyma in transversal section; (C) charcoal produced at $380{ }^{\circ} \mathrm{C}$; (D) microstructure details of charcoal produced at $380^{\circ} \mathrm{C}$ in transversal section. 


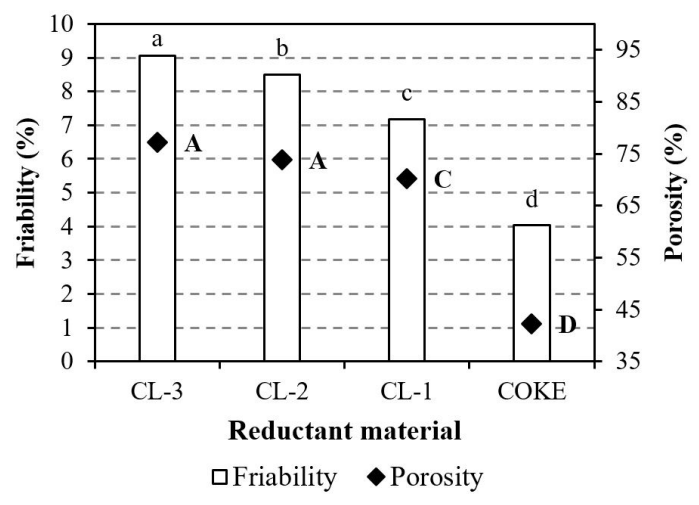

Figure 5. Friability and porosity of Eucalyptus wood chars and coke. Standard deviation $=0.83$ (friability), 3.6 (porosity); variation coefficient $=11.5 \%$ (friability), $5.5 \%$ (porosity). Means followed by same letter do not differ at $5 \%$ probability by the Tukey test.

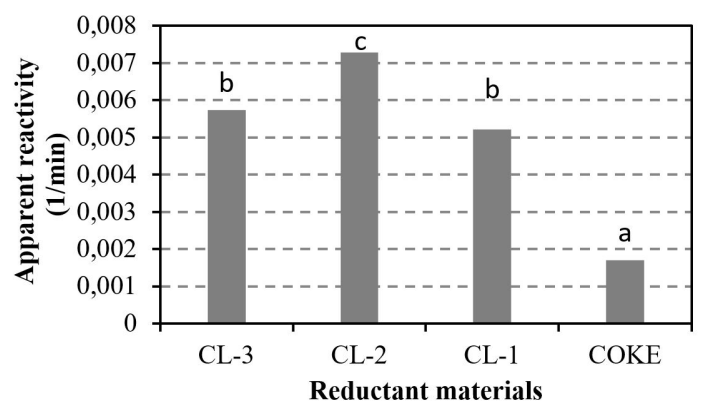

Figure 6. $\mathrm{CO}_{2}$ gasification reactivity of Eucalyptus wood chars and coke. Standard deviation $=0.000341$; variation coefficient $=5.7 \%$. Means followed by same letter do not differ at $5 \%$ probability by the Tukey test.

has high probability to diffusion deeply into the particle before reacting with the pore surface. The gaseous reactant concentration is necessarily uniform throughout the porous solid. Therefore, reactions are generally controlled by chemical reaction (Radovic et al., 1983).

\section{CONCLUSION}

There is wood variability among evaluated clones and strong correlations between wood and charcoal properties. The high apparent density and low porosity values of charcoal were mainly related with higher bulk wood density. In addition, the high charcoal porosity led to high friability.

Wood anatomical characteristics, such as shape, arrangement and organization showed little or no alteration due to slow pyrolysis and the charcoal surface presented well defined structures.

All charcoals from Eucalyptus clones had higher reactivity values when compared to coke. The decrease in porosity and increase apparent density values in Eucalyptus wood char led to a slightly decreased $\mathrm{CO}_{2}$ gasification reactivity.

In this work, strong correlation between charcoal reactivity and $\mathrm{K}$ concentration was found.

\section{ACKNOWLEDGMENTS}

The authors gratefully acknowledge the financial support from the Brazilian Federal Government Agency (CAPES - scholarship) and Research Council of Norway and the partners of SFI Metal Production.

\section{SUBMISSION STATUS}

Received: 27 nov., 2018

Accepted: 13 dec., 2018

\section{CORRESPONDENCE TO}

\section{Bárbara Luísa Corradi Pereira}

Departamento de Engenharia Florestal, Universidade Federal de Mato Grosso - UFMT, Av. Fernando Corrêa da Costa, 2367, Boa Esperança, CEP 78060-900, Cuiaba, MT, Brasil e-mail: babicorradi@gmail.com

\section{REFERENCES}

American Society for Testing and Materials - ASTM. Standard test method for chemical analysis of wood charcoal-D1762-84. Philladelphia: ASTM; 2013.

Assis MR, Brancheriau L, Napoli A, Trugilho PF. Factors affecting the mechanics of carbonized wood: literature review. Wood Science and Technology 2016; 50(3): 519-536. http://dx.doi.org/10.1007/s00226-016-0812-6.

Associação Brasileira de Normas Técnicas - ABNT. NBR 11941: Wood: Determination of the basic density. Rio de Janeiro: ABNT; 2003.

Babich A, Senk D, Fernandez M. Charcoal behavior by its injection into the modern blast furnace. ISIJ International 2010; 50(1): 81-88. http://dx.doi.org/10.2355/ isijinternational.50.81.

Costa ACS, Leal CS, Santos LC, Carvalho AMMC, Oliveira AC, Pereira BLC. Properties of heartwood and sapwood 
of Eucalyptus camaldulensis. Brazilian Journal of Wood Science 2017; 8(1): 10-20.

Couto AM, Trugilho PF, Napoli A, Lima JT, Silva JRM, Protásio TP. Quality of charcoal from Corymbia and Eucalyptus produced at different final carbonization temperatures. Scientia Forestalis 2015; 43(108): 817-831. http://dx.doi.org/10.18671/scifor.v43n108.7.

Gładysz J, Karbowniczek M. Carbon reducers for the processes of ferroalloy production in the electric furnace. Archives of Metallurgy and Materials 2008; 53(2): 643-648.

Gomide JL, Demuner BJ. Determination of lignin in woody material: modified Klason method. O Papel 1986; 47(8): 36-38.

Kaczorowski J, Lindstad T, Syvertsen M. The influence of potassium on the boudouard reaction in manganese production. ISIJ International 2007; 47(11): 1599-1604. http://dx.doi.org/10.2355/isijinternational.47.1599.

Kan T, Strezov V, Evans TJ. Lignocellulosic biomass pyrolysis: A review of product properties and effects of pyrolysis parameters. Renewable \& Sustainable Energy Reviews 2016; 57(1): 1126-1140. http://dx.doi.org/10.1016/j. rser.2015.12.185.

Mitsuoka K, Hayashi S, Amano H, Kayahara K, Sasaoaka E, Uddin A. Gasification of woody biomass char with $\mathrm{CO}_{2}$ : The catalytic effects of $\mathrm{K}$ and $\mathrm{Ca}$ species on char gasification reactivity. Fuel Processing Technology 2011; 92(1): 26-31. http://dx.doi.org/10.1016/j.fuproc.2010.08.015.

Neves TA, Protásio TP, Couto AM, Trugilho PF, Silva VO, Vieira CMM. Evaluation of Eucalyptus clones in different places seeking to the production of vegetal charcoal. Pesquisa Florestal Brasileira 2011;31(68): 319-330. http:// dx.doi.org/10.4336/2011.pfb.31.68.319.

Noumia ES, Rousset P, Carneiro ACOC, Blin J. Upgrading of carbon-based reductants from biomass pyrolysis under pressure. Journal of Analytical and Applied Pyrolysis 2016; 118(1):278-285. http://dx.doi.org/10.1016/j.jaap.2016.02.011.

Oliveira AC, Carneiro ACO, Vital BR, Almeida W, Pereira BLC, Cardoso MT. Quality parameters of Eucalyptus pellita F. Muell. wood and charcoal. Scientia Forestalis 2010; 38(87): 431-439.

Pereira BLC, Oliveira ACO, Carvalho AMML, Carneiro ACOC, Vital BR, Santos LC. Quality of wood and charcoal from eucalyptus clones for iron master. International Journal of Forestry Research 2012; 2012(1): 1-8. http:// dx.doi.org/10.1155/2012/523025.

Pereira BLC, Carneiro ACO, Carvalho AMML, Colodette JL, Oliveira AC, Fontes MPF. Influence of chemical composition of Eucalyptus wood on gravimetric yield and charcoal properties. BioResources 2013a; 8(3): 45744592. http://dx.doi.org/10.15376/biores.8.3.4574-4592.

Pereira BLC, Carneiro ACOC, Carvalho AMML, Trugilho PF, Alves ICN, Oliveira ACO. Study of thermal degradation of eucalyptus wood by thermogravimetry and calorimetry. Revista Árvore 2013b; 37(3): 567-576. http://dx.doi.org/10.1590/S0100-67622013000300020.
Pereira BLC, Oliveira AC, Carvalho AMML, Carneiro ACO, Vital BR, Santos LC. Correlations among the heart/ sapwood ratio of eucalyptus wood, yield and charcoal properties. Scientia Forestalis 2013c; 41(98): 217-225.

Pereira BLC, Carvalho AMML, Oliveira AC, Santos LC, Carneiro ACO, Magalhães MA. Effect of wood carbonization in the anatomical structure and density of charcoal from Eucalyptus. Ciência Florestal 2016; 26(2): 545-557. http:// dx.doi.org/10.5902/1980509822755.

Raad TJ, Pinheiro PCC, Yoshida MI. General equation of kinetic mechanism of carbonization of Eucalyptus sp. Cerne 2006; 12(2): 93-106.

Radovic LR, Walker PL Jr, Jenkins RG. Importance of carbon active sites in the gasification of coal chars. Fuel 1983; 62(7): 849-856. http://dx.doi.org/10.1016/00162361(83)90041-8.

Sakurovs R, Burke L. Influence of gas composition on the reactivity of cokes. Fuel Processing Technology 2011; 92(1): 1220-1224. http://dx.doi.org/10.1016/j.fuproc.2011.01.019.

Santos RC, Carneiro ACO, Vital BR, Castro RVO, Vidaurre GB, Trugilho PF et al. Effect of properties chemical and siringil/guaiacil relation wood clones of eucalyptus in the production of charcoal. Ciência Florestal 2016; 26(2): 657-669. http://dx.doi.org/10.5902/1980509822765.

Siebeneichler EA, Costa LM, Figueredo NA, Tronto J, Rocha PA. Influence of temperature and heating rates on mechanical resistance, density and yield of the wood charcoal of Eucalyptus cloeziana. Brazilian Journal of Wood Science 2017; 8(2): 82-94.

Silverio FO, Barbosa LCA, Maltha CRA, Fidêncio PH, Cruz MP, Veloso DP et al. Effect of storage time on the composition and contente of wood extractives in Eucalyptus cultivated in Brazil. Bioresource Technology 2008; 99(1): 4878-4886. http://dx.doi.org/10.1016/j. biortech.2007.09.066. PMid:17988861.

Soares VC, Bianchi ML, Trugilho PF, Pereira AJ, Höfler J. Correlations between the properties of eucalyptus hybrids wood and charcoal. Revista Árvore 2014; 38(3): 543-549. http://dx.doi.org/10.1590/S0100-67622014000300017.

Technical Association of the Pulp and Paper Industry TAPPI. TAPPI test methods T 204 om-88: Solvent extractives of wood and pulp, in TAPPI Standard Method. Atlanta: Tappi Technology Park; 2001. (CD-ROM).

Trugilho PF, Lima JT, Mori FA, Luiza LA. Evaluation of Eucalyptus clones for charcoal production. Cerne 2011; 7(2): 104-114.

Wang L, Hovdb B, Buib HH, Valderhaugc A, Buøc TV, Birkelandc RG et al. $\mathrm{CO}_{2}$ Reactivity assessment of woody biomass biocarbons for metallurgical purposes. Chemical Engineering Transactions 2016; 50(1): 55-60.

Yang H, Yan R, Chen H, Lee DH, Zheng C. Characteristics of hemicellulose, cellulose and lignin pyrolysis. Fuel 2007; 86(12): 1781-1788. http://dx.doi.org/10.1016/j. fuel.2006.12.013. 